\title{
The future of conservation and development in Madagascar: time for a new paradigm?
}

\author{
Ivan R. Scales
}

\begin{abstract}
The history of conservation policy and practice in Madagascar over the last 30 years shows that the Malagasy government, donors and non-governmental organisations (NGOs) have not been short of bold solutions, with ambitious attempts to involve local communities in resource management as well as expand protected areas. While there have been notable achievements, continued threats to the island's flora and fauna, as well as the negative impacts that conservation policy has often had on rural livelihoods, show that there is still much to be done. So what are the lessons from the past and the challenges ahead? In this paper I provide a broad overview of recent research in the social sciences on conservation and development in Madagascar. I argue that conservation science and policy have often been based on overly simplistic understandings of humanenvironment interactions and sometimes even plain myths. This has contributed to a narrow policy vision, with important issues and ecosystems receiving less attention. Furthermore, conservation policy continues to be based on a highly uneven distribution of costs and benefits. In order to address these limitations, research and policy must do more to deal with differences in perceptions, priorities and power and be willing to embrace trade-offs between various conservation and development goals.
\end{abstract}

\section{RÉSUMÉ}

L'histoire de la politique et la pratique de la protection de la nature à Madagascar au cours des 30 dernières années montre que le gouvernement malgache, les donateurs, et les organisations non-gouvernementales (ONG) n'ont pas manqué de grandes solutions. Cela inclut l'implication des communautés locales dans la gestion des ressources naturelles ainsi que l'expansion des aires protégées. Malgré des réussites notables, il reste beaucoup à faire car la biodiversité continue d'être menacée et les politiques adoptées ont souvent eu des impacts négatifs sur les moyens d'existence des ménages ruraux. Quelles sont les leçons à tirer du passé et les défis à relever pour le futur? Au cours des deux dernières années, j'ai eu le privilège d'être le rédacteur et coordinateur d'une publication sur la 'Conservation et la Gestion de I'Environnement à Madagascar' (Routledge, Londres). Je me propose de résumer ici les thèmes, les enjeux et les débats qui ont émergé de cette publication. Mon argument principal est que la science et la politique de la conservation

\author{
St Catharine's College \\ University of Cambridge \\ U.K. \\ E-mail:irs28@cam.ac.uk
}

à Madagascar ont souvent été basées sur une conception étroite des interactions entre l'homme et l'environnement, en particulier sur les facteurs sociaux, politiques et économiques de l'utilisation des ressources naturelles et la dégradation de l'environnement. Les histoires de crise jalonnent le discours environnemental de Madagascar dans lequel dominent les problématiques. Le leitmotiv le plus commun, qui est aussi le plus problématique, porte sur l'idée que le déboisement de l'île a été de $90 \%$. Ce 'fait' est souvent énoncé dans la littérature académique et généralement repris les organisations de conservation de la nature afin de montrer l'urgence du problème de la dégradation de l'environnement. En conséquence les zones herbeuses de l'île sont tout simplement perçues comme des paysages dégradés. Un autre leitmotiv concerne la culture sur brûlis qui est imputée à la pauvreté et une ignorance de 'meilleures' pratiques. Ces formules galvaudées ont contribué à une politique aux perspectives restreintes dans laquelle certaines problématiques et des écosystèmes importants ne reçoivent pas les considérations qu'ils méritent. Elles ont également contribué à établir des 'forteresses de la conservation' qui sont essentiellement fondées sur l'exclusion des paysans malgaches des zones protégées avec son lot de conséquences sur les moyens d'existence des populations rurales. Malgré les efforts déployés pour impliquer les communautés rurales dans la gestion des ressources naturelles, la politique continue d'aboutir à une répartition inégale des coûts et des avantages. Pour trouver une solution, la recherche et les politiques doivent adopter un nouveau paradigme qui : i) s'éloigne des récits et des mythes problématiques; ii) reconnaisse les différences dans les perceptions et les priorités des divers acteurs; iii) adopte I'arbitrage entre les différents objectifs de conservation et de développement; et iv) englobe un ensemble plus diversifié de voix et d'opinions.

\section{INTRODUCTION}

The central challenge for conservation policy in Madagascar needs little introduction to readers of this journal: how to protect the island's remarkable biological diversity at the same time as improving the livelihoods of the millions of people directly dependent on its ecosystems for their livelihoods? As Bill McConnell (2002: 10) reminds us "Few places on Earth evoke such simultaneous awe and consternation as Madagascar, a country with unique biological riches on a seemingly immuta- 


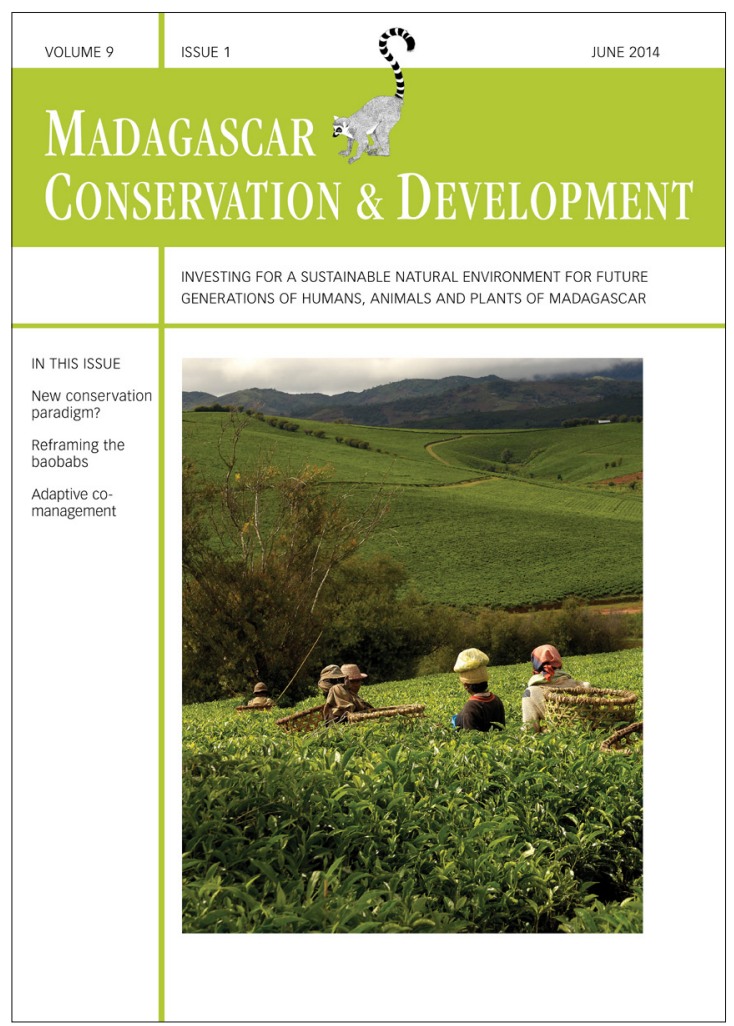

Madagascar Conservation \& Development is the journal of Indian Ocean e-Ink. It is produced under the responsibility of this institution. The views expressed in contributions to MCD are solely those of the authors and not those of the journal editors or the publisher.

All the Issues and articles are freely available at http://www.journalmcd.com

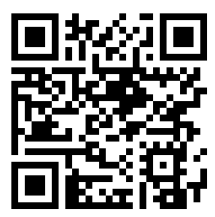

Contact Journal MCD

info@journalmcd.net for general inquiries regarding MCD funding@journalmcd.net to support the journal

Madagascar Conservation \& Development Institute and Museum of Anthropology University of Zurich

Winterthurerstrasse 190

$\mathrm{CH}-8057$ Zurich

Switzerland

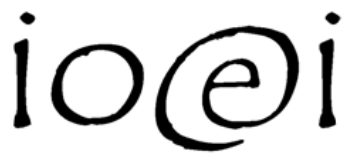

Indian Ocean e-Ink

Promoting African Publishing and Education www.ioeink.com

Missouri Botanical Garden (MBG)

Madagascar Research and Conservation Program BP 3391

Antananarivo, 101, Madagascar 
ble path of impoverishment". The history of policy and practice over the last 30 years shows that the Malagasy government, donors and non-governmental organisations (NGOs) have not been short of bold solutions, from the National Environmental Action Plan (NEAP) launched in 1991, to attempts to devolve natural resource management to communities through the Gestion Locale Sécurisée (GELOSE) law of 1996, and the tripling of the island's protected areas under the 2003 Durban Vision.

There have been some notable achievements, including the greater participation of local stakeholders in resource management, as well as efforts to generate alternative sources of income for rural households so that their livelihoods place less pressure on ecosystems and habitats (Ferguson and Gardner 2010). However, the continued loss and fragmentation of forest (Harper et al. 2007); the recent increase in the illegal trade in exotic hardwoods (Schuurman and Lowry 2009); the exploitation of protected species through bushmeat consumption (Jenkins et al. 2011); and the negative impacts that conservation policy has often had on rural livelihoods (Ghimire 1994, Ferraro 2002) show that there is still much to be done.

While the island's flora and fauna have received considerable attention, including prime time wildlife documentaries and landmark publications such as The Natural History of Madagascar (Goodman et al. 2003), the human dimensions of environmental change in Madagascar have received less publicity. This belies the fact that there has been a wealth of research, with insights coming from a wide range of disciplines, including anthropology, economics, geography, political science, environmental history, archaeology and palaeoecology. There have been significant efforts to better understand the drivers of natural resource use decisions and environmental degradation in different geographical and historical contexts, as well as the impacts of conservation policy on rural livelihoods (both positive and negative). So what can we take away from these efforts? What are the lessons from the past and priorities for the future?

Over the course of the last two years I have had the privilege of editing a book on 'Conservation and Environmental Management in Madagascar' (Routledge, London). This has brought me into contact with a diverse range of academics and practitioners, who together have many lifetimes of experience of research and policy implementation. The aim of this paper is to distil the key themes, issues and debates that have emerged from the book. My central argument is that conservation science and policy have often been based on a narrow understanding of complex and diverse human-environment interactions, especially in terms of the social, political and economic drivers of natural resource use and environmental degradation. This has led to a 'fortress conservation' policy approach based primarily on excluding people from protected areas and has had serious implications for rural livelihoods. Despite efforts to involve communities in resource management, policy continues to lead to a highly uneven distribution of costs and benefits. In order to address these limitations research and policy must embrace a new paradigm that: i) moves away from problematic narratives and myths about human-environment interactions; ii) acknowledges differences in perceptions and priorities between different stakeholders; iii) embraces trade-offs between various conservation and development goals; and iv) opens up environmental discourse and decision-making to include a more diverse set of voices and opinions.

\section{MOVING BEYOND STORIES, MYTHS AND OVER- SIMPLIFICATIONS}

When reading about environmental issues in Madagascar whether in the scientific literature, travel guides or the media - one tends to come across a set of recurring stories. The most influential idea, critiqued by authors such as Kull (2000), McConnell (2002) and Dewar (2014), is that of an Eden-like island-wide forest ruined by the arrival of humans. The other common theme, highlighted and critiqued by authors such as Kull (2000), McConnell (2002), Pollini (2010), Scales (2011) and Horning (2012), is the continued devastation of delicate ecosystems by the actions of rural households, who are portrayed as too poor and too stubborn to change their destructive ways. The island's environmental history is thus held up as a cautionary tale of what happens when untouched nature is suddenly subjected to humanity's rapacious tendencies.

Madagascar's environmental discourse is full of stories of crisis and impending doom (Scales 2014a). Such 'narratives' play a major role in shaping environmental policy, helping people to weave bits of information together into a coherent account of why environmental problems occur and how they might be solved (Dryzek 1997). Although useful in helping people to understand the world, these environmental narratives can be problematic, especially when it turns out that they have little empirical basis. As Kull argues (2000: 441): "Received wisdoms about the environmental history of Madagascar include much confusion, misunderstanding and misinterpretation."

The clearest example of problematic narratives in Madagascar's environmental discourse is the ' $90 \%$ ' deforestation statistic that is liberally cited in the academic literature and trotted out by conservation NGOs to show just how urgent the conservation problem is: "Much of the justification for conservation action depends on descriptions of previously extensive forests being cut and burned, on documentation of the threats to the patches that remain, and on success in slowing or stopping deforestation." (McConnell and Kull 2014: 67).

However, the $90 \%$ deforestation 'fact' is ultimately based on the assumption that Madagascar was more-or-less entirely covered in forest before human arrival. There is in reality little evidence that the island has ever been entirely forested: "Many popular discussions contrast modern landscapes with the 'original vegetation' of Madagascar as part of a narrative in which people arrived on the island, destroyed the forest, and thereby unleashed a wave of extinctions. This is a problematic way to frame the discussion, in light of mounting palaeoecological evidence of landscapes in continuous, if usually slow, change. The phrase 'original vegetation' is commonly used to refer to the vegetative cover at the very beginning of human activity in Madagascar, but this implies a more confident understanding of the early period of Malagasy prehistory than we currently possess." (Dewar 2014: 55).

Recent empirical evidence points to more complex pre-human vegetation dynamics and the importance of grasslands in their own right (Burney et al. 2004, Wilmé et al. 2006, Bond et al. 2008, Virah-Sawmy 2009, Mercier and Wilmé 2013, Ganzhorn et al. 2014). This is not to deny that humans have had considerable impacts on the island's flora and fauna. Rates of forest loss over the last fifty years in particular are a cause for concern and forest clearance agriculture has been the principle land use responsible for land cover change (Harper 
et al. 2007). However, deforestation is sufficiently alarming without resorting to dubious statistics: "The loss of forest in some portions of the island is (...) dramatic enough that such exaggerations are unnecessary. These exaggerations are even potentially harmful in that they can undermine scientific authority, put blinders on the types of questions that are asked, and push to the sidelines important debates about the impacts of strong conservation policies on rural people." (McConnell and Kull 2014: 67-68). As well as these issues regarding the extent of environmental change, the received wisdom is also based on problematic assumptions about the drivers of resource use and environmental degradation. Environmental narratives are often explicitly neo-Malthusian: "(...) the poverty that afflicts Madagascar's people threatens to destroy what remains of this unique biology (...) widespread poverty, increasing population, and the absence of resources and techniques to improve the productivity of agricultural and pasture lands have led to massive deforestation (...)." (Sussman et al. 1994: 334).

Once again, this oversimplifies human-environment interactions. Research suggests that the drivers of environmental change are more diverse and nuanced than simply population growth and poverty. It is true that humans have played a significant role in shaping the island's landscapes and contributed to species extinctions through hunting, forest clearance, livestock practices and the introduction of non-native species (Dewar 1984, Burney et al. 2004, Dewar 2014). It is also clear that population growth and poverty can constrain the livelihood choices of rural households (Casse et al. 2004, Scales 2011, Scales 2014b). However, contrary to the received wisdom, environmental degradation is not driven purely by the need to feed a growing population. For example, studies of the causes of deforestation have identified a wide range of factors including cash cropping by wealthy rural households using migrant labor (Minten and Méral 2006, Scales 2011); cash cropping by migrants to build-up wealth and purchase zebu cattle before returning home (Réau 2002); the establishment of foreign- owned large-scale plantations (Jarosz 1993, Scales 2011); and increases in global commodity prices stimulating the expansion of cash crops (Casse et al. 2004, Minten and Méral 2006).

In general, the relationship between poverty, population growth, economic growth and natural resource use is far more complex than the received wisdom makes out (Jolly 1994, Geist and Lambin 2002, Carr 2004, Carr et al. 2006). This is important, as research and policy in Madagascar tend to focus on the activities of poor rural households at the expense of paying more attention to the role of powerful elites or external drivers of forest loss. Policies have often been built on the implicit assumption that raising income in rural areas will solve problems of environmental degradation. However, as Kull (2000: 433) points out "Give the average Malagasy tavy farmer more money, and deforestation may just as well increase as they utilise better tools and pay for additional labour." This suggests that policy and research need to give greater consideration to the cultural and institutional dimensions of livelihoods, rather than assuming a simple relationship between economic growth and natural resource use. Ultimately, simplistic narratives and myths about environmental degradation hinder progress and limit options.

\section{THE NARROW VISION OF CONSERVATION AND DEVELOPMENT}

The received wisdom is important because it has played a major role in influencing the research and policy agenda in Madagascar (Kull 2014, McConnell and Kull 2014, Scales 2014C). The tendency to see Madagascar's forests as the last bastions of the island's biodiversity (and the last remnants of an islandwide forest) has led to rather narrow 'fortress conservation' mentality that has focused on excluding people from protected areas as well as limiting practices such as swidden cultivation and grassland burning.

From a conservation perspective it is understandable that attention and efforts have tended to concentrate on protecting Madagascar's remaining forests, since they contain the majority of the island's endemic terrestrial biodiversity (Goodman and Benstead 2005). It is also important to note that there have been efforts to ensure that protected areas reflect the diversity of the island's various ecosystems (Kremen et al. 2008, Rasoavahiny et al. 2008). There have been efforts to broaden the scope of the island's protected area network to incorporate IUCN (International Union for the Conservation Nature) Category V (Protected Landscape) and Category VI (Protected Area with Sustainable Use of Natural Resources), which allow some human land uses and include cultural as well as biological values. Projects have also sought to involve communities in conservation activities, most notably through GELOSE (Gestion Locale Sécurisée) and GCF (Gestion Contractualisée des Forêts).

Despite these laudable efforts, there are still considerable gaps in our knowledge of human-environment interactions and ecological change on the island. Because of the myth of the island-wide forest, Madagascar's grasslands have been especially neglected. Policy tends to operate on the assumption that they are simply degraded landscapes and thus not worthy of research or policy attention (Dewar 2014). Grasslands tend to be viewed as 'unnatural' landscapes, created through forest clearance for agriculture and burning grasslands for pasture. Pollen records show that grasslands have a long history and likely invaded Madagascar millions of years ago as part of a worldwide expansion of grassy biomes (ibid). Recent research on the island's grasslands has revealed the diversity of their flora and fauna, with the presence of numerous endemic species: "We suggest that biologists should take a fresh look at Madagascan grasslands, not least because the grassland biota has been largely neglected in biological inventories for conservation in a country characterized by almost unparalleled levels of endemism. Grassy ecosystems in general have been viewed as an alien, rather than intrinsic, component of this extraordinary island." (Bond et al. 2008: 1753).

In general, far too little is known about the spatial and temporal dynamics of environmental change. Palaeoecology shows us that Madagascar's diverse ecosystems have followed different trajectories, yet little is known about the specifics of vegetation change or the role of human action (Kull 2000, Dewar 2014). This is especially the case with fire, which has a deep history on the island, pre-dating human presence (Burney 1987, Gasse and Van Campo 2001). While fire has received considerable attention as a policy issue, our knowledge of its role in different ecosystems is still poor: "Until recently, it was supposed that the first people on Madagascar imported fire, and the result was a gigantic conflagration utterly destructive to a forested but fragile landscape. 
(...) That view now appears wrong for at least two reasons. First, the palaeoecological research of the last quarter century makes clear that periodic fires have been an important element of many Malagasy ecosystems for tens of thousands of years. (...) A second reason for rejecting the 'gigantic conflagration' view is that Malagasy plant formations are not uniformly vulnerable to fire (...). Replacing 'gigantic conflagration' is evidence that specific vegetational changes over the past 2,000 years have many causes, some related to pastoralism, some to the introduction of crops and fields, some to forestry and logging, and some to substantial environmental degradation in the vicinity of high populations... Much research is still needed to piece together accurate, place-specific accounts, and major puzzles remain." (Dewar 2014: 56).

\section{THE UNEVEN DISTRIBUTION OF COSTS AND BENEFITS IN CONSERVATION PROJECTS}

As well as driving a narrow research and policy agenda, the focus of environmental discourse on 'fortress conservation' and the idea of an 'island forest' have contributed to conservation practices with a highly uneven distribution of costs and benefits. The establishment of protected areas has led to severe restrictions on natural resource use and the disruption of livelihoods, property systems and cultural values (Ghimire 1994, Peters 1999, Pollini 2011). For example, a study of the impact of Ranomafana National Park estimated the cost of lost access to natural resources to be \$US39/year per household, equivalent to as much as $25 \%$ of household income (Ferraro 2002).

In an attempt to improve the performance of protected areas, as well as create incentives for conservation and generate alternative sources of income for rural households, conservation organizations and government ministries have experimented with a wide range of schemes. Policy has increasingly turned to incentive-based mechanisms that attempt to create financial motives for conservation. Tourism in particular continues to be promoted by some researchers and policymakers as a strategy for reconciling conservation and development goals. For example, in a recent paper on lemur conservation published in the journal Science, Schwitzer et al. (2014: 843) advocate 'eco'-tourism as the ideal way to address the issue of funding conservation and integrating conservation and development: "Promoting and expanding ecotourism is one important component of the action plan. Lemurs represent Madagascar's most distinctive 'brand' for tourism. Ecotourism continues in spite of political problems and remains one of the country's most important foreign-exchange earners, providing livelihoods for the rural poor in environmentally sensitive regions and often fostering local valuation of primates and ecosystems."

As well as tourism, we have seen a recent flourishing of schemes based on payments for environmental services (PES). Both tourism and PES offer the tantalising prospect of generating funds from forests and other ecosystems without directly consuming any natural resources. Given the severity and urgency of biodiversity conservation and poverty alleviation, it is little surprise that policymakers have sought a 'miracle cure' to tackle both at the same time.

The history of tourism-based conservation in Madagascar offers some important lessons about the challenges of integrating conservation and development and demonstrates how uneven the distribution of costs and benefits of conser- vation can be. The most significant problem is that tourism has mostly been incapable of generating sufficient income. At present, it is concentrated in a few geographical regions and a small number of protected areas. According to Christie and Crompton (2003), four national parks (Andasibe-Mantadia, Isalo, Ranomafana, Montagne d'Ambre) and one special reserve (Ankarana) attracted over $88 \%$ of the visitors between 1992 and 2000. Even for these parks there are limitations to how much tourism can achieve.

In theory tourism can create a range of benefits, ranging from a share of revenue from park entrance fees to employment opportunities and broader benefits to local economies through tourist spending and infrastructural improvements. However, there are significant barriers to tourism's usefulness as a tool for conservation. Firstly, there is the problem of the scale at which benefits are distributed. Most attempts to share benefits and create incentives have been at the community level. For example, a share of entrance fees is given to a management committee to be used for development projects such as the provision of healthcare and education facilities (Durbin and Ratrimoarisaona 1996). In Masoala National Park visitor fees have been used for road improvements, the construction of wells and sanitation projects (Ormsby and Mannie 2006). However, while the benefits accrue at the community level, the costs of loss of access are experienced at the individual or household level. There is thus a disconnect between the costs incurred and the benefits gained. As Durbin and Ratrimoarisaona have argued (1996: 351), "(...) it is hard to see how these community-level benefits will change the behaviour of individual households that rely for most of their livelihood on exploiting resources within the parks."

In terms of benefits for individuals and households, these are largely insufficient to replace activities such as swidden cultivation. A study of the impact of tourism on communities living around Ranomafana National Park found that it directly employed just over 100 people (with less than half coming from the local population of 27,000 ), indirectly benefited fewer than 100 people, and led to infrastructural improvements in fewer than a dozen of the 160 villages surrounding the park (Peters 1998,1999 ). The reality is that tourism (and conservation more generally) has created few employment opportunities, with those available tending to favour more educated individuals with the necessary language skills to deal with tourists (Durbin and Ratrimoarisaona 1996, Walsh 2005). In the Mikea Forest for example, economic benefits accrue to a minority of hotel owners and staff, most of whom come from outside the region (Seddon et al. 2000). Walsh (2005) reminds us that the majority of people living around protected areas in Madagascar do not have the skills or connections necessary to profit from conservation related activities. The challenge for conservation policy is clear. Unless it is able to create livelihood alternatives that at the very least match previous sources of income, consumptive uses such as swidden cultivation will continue, covertly and against the law if necessary.

\section{NEGOTIATING DIFFERENCES IN PERCEPTIONS, PRIORITIES AND POWER}

Despite efforts to involve communities in decision-making and create alternative sources of income for rural households, conservation in Madagascar has remained largely top-down (Corson 2010, Dressler et al. 2010, Pollini 2011, Corson 2014, 
Pollini et al. 2014). The biggest constraint for local participation in natural resource management is that the conservation bureaucracy has largely held the opposing goal, namely limiting access to natural resources through protected areas and banning local resource use practices such as swidden cultivation (Dressler et al. 2010). The rush to implement the Durban Vision has not helped matters, overriding any meaningful attempts to engage communities (Dressler et al. 2010, Corson 2014, Pollini et al. 2014). Following Marc Ravalomanana's 2003 announcement that the coverage of protected areas would be tripled within five years, it proved impossible to consult all the rural villages potentially affected by the expansion (Corson 2014). The end result was that the 'consultation' process was in fact more of an awareness raising exercise aimed at 'educating' rural households than a genuine attempt to incorporate the views and wishes of people living in and around the expanded protected areas (ibid)

As well as the expansion of protected areas, the last ten years have seen the rapid growth in biodiversity-offsets and PES schemes (Seagle 2012, Brimont and Bidaud 2014). These are part of a global trend of 'green capitalism' that has seen conservation NGOs become ever closer to big business (Scales, in press). Carbon credits in particular are considered to be a major potential source of funds for forest conservation and development, with rural households paid to maintain forest cover and the carbon sequestration services that come with intact forests (Bekessy and Wintle 2008, Brimont and Bidaud 2014). As with tourism, the 'win-win' logic is compelling. However, such projects shine a light on the power dynamics of environmental management and the relationship between big business and conservation. International conservation NGOs have positioned themselves as gatekeepers, providing authoritative knowledge about biodiversity and ecosystems to businesses and governments (MacDonald 2010). Conservation organisations have moved from critiquing the activities of large corporations to playing a key role in enabling businesses to expand into new areas (Fairhead et al. 2012).

Looking at biodiversity offsets in southeastern Madagascar for example, these have seen close relations between mining companies and international conservation organisations. Conservation NGOs have formed a partnership with Rio Tinto/QMM, providing assistance with biodiversity offsetting and receiving funding for conservation activities in the process (Seagle 2012). Rio Tinto has been able to exert considerable influence over conservation activities, negotiating the boundaries and rights associated with new protected areas and helping to reduce the constraints that these areas might place on the rapidly expanding mining industry (Seagle 2012, Corson 2014). At the same time, the new areas that have been 'offset' for biodiversity have limited local natural resource use rights (ibid). In other words, powerful business interests get to carry out extractive activities, while rural households do not. These developments have helped to reinforce the high levels of political influence that international conservation organisations have in Madagascar (Duffy 2006, Corson 2010, Kull 2014).

The experiences of GELOSE, the Durban Vision and more recent attempts to involve communities in incentive-based conservation raise questions about participation and power. The danger in attempts towards greater community involve- ment in conservation is that policymakers end up 'playing with anthropology' (Kaufmann 2014). In other words, they attempt to involve people in conservation projects, without a sufficient understanding of their often very different worldviews and institutions. The result has been clumsy attempts to blend local cultural values (especially fady) and institutions (especially dina) with a western conservation ethic (Keller 2009, Scales 2012, Kaufmann 2014, Pollini et al. 2014). The different aims and perspectives of rural households and communities are often 'Iost in translation' (Scales 2012). Inevitably, the weaker side is asked to give in to the more powerful side (Kaufmann 2014).

The problem with any attempt at widening participation in environmental decision-making is that different individuals and groups want different things. The conservation of biological diversity and management of natural resources involves multiple stakeholders, often with conflicting priorities. Ultimately, it means they see Madagascar's biodiversity in contrasting ways. For example Thalmann (2006: 6) has labelled the island's primates 'Ambassadors for Madagascar': "As a primate group endemic to Madagascar they constitute a unique part of the world's natural heritage and a unique part of humankind's natural history. Being mostly forest dwelling animals they may serve as ambassadors for the forests of Madagascar and the whole wildlife in these forests all over the island where it remains. Lemur conservation equals forest conservation. (...) Because lemur conservation is forest conservation, the protection of lemurs also helps to grant important services by forests, such as reduced erosion, clear and sustainable water proliferation - 'a better life for humans'[emphasis added]."

The last part of the quotation above would be contested by many Malagasy living at the forest frontier. The protection of the island's flora and fauna has in fact mainly resulted in loss of access to natural resources. Furthermore, while outsiders may see practices such as swidden cultivation and grassland burning as irrational and destructive, rural households see them as ways of making land productive and feeding their families (Scales 2012, 2014b). As Christian Kull (2000a: 433) puts it: "Malagasy farmers are not sacrificing nature for short-term needs, they are instead transforming nature to be of more use to them. It is a matter of perspective." While biologists rightly describe the island as a naturalist's paradise, those living at the forest frontier are often left to wonder whether conservationists care more about lemurs than they do about people (Peters 1998, Harper 2002).

Ultimately, local participation will have to involve trade-offs between different goals and conservation and environmental management should involve a two-way conversation with the potential for negotiation, rather than a one-way imposition of external ideas (Richard and Dewar 2001). This means "(...) resisting the temptation to obscure political realities, flatten multiple dimensions of value into a single term, or ignore marginalized interests or ways of knowing (...)" (Hirsch et al. 2011: 263). Policy that starts by presenting communities with a fait accompli is doomed to failure. Households must make a living somehow. As Cronon (1996: 16) argues: "The dream of an unworked natural landscape is very much the fantasy of people who have never themselves had to work the land to make a living." 


\section{CONCLUSIONS}

The task of successfully integrating conservation and development in Madagascar can seem daunting. How can policy balance the various perceptions and priorities of multiple stakeholders? How can it protect biodiversity at the same time as delivering livelihood alternatives? How does it increase local participation in decision-making in a political environment that has repeatedly proven to be unstable and prone to crisis?

As I have already mentioned, there are rarely 'win-wins' in conservation. Socio-ecological problems are complex and context specific, defying 'magic bullets' (Ostrom et al. 2007). A good place to start would be for conservation policymakers to acknowledge this. I believe that the most significant change needs to be in the mindset that underpins environmental discourse in Madagascar. As it stands, research and policy are stuck in a rigid paradigm. I use the term paradigm in the sense first coined by Thomas Kuhn (1962) to describe how scientific fields stabilise around a key set of assumptions, questions and methods. During such phases, Kuhn argued that research tends to be conservative, resisting change. Judging by these criteria, I believe that conservation and development in Madagascar is paradigmatic. It has its own language and narratives (Kull 2000, Pollini 2010, Scales 2012); it tends to rely on a rather limited set of research methods and policy approaches (Scales 2012, McConnell and Kull 2014); and it is underpinned by certain problematic assumptions, most obviously the idea of Eden-like virgin forest destroyed by human short-sightedness (McConnell 2002, Dewar 2014, McConnell and Kull 2014).

Instead of searching for panaceas, conservation policy in Madagascar needs to open itself to new ideas and approaches. In the words of Bill Adams (2003: 209): "There is no right way to do conservation. There are only choices." In the process of making these choices, conservation must embrace a plurality of values. This won't be easy and environmental policy will invariably be messy and contingent on local realities (Scales 2014C). However, as argued by Horning (2012), we can start the process by opening up the conservation and development 'thinking club' so that it reflects a more diverse set of views and possibilities. We need more conversations between different academic disciplines (biologists, anthropologists, archaeologists, economists, environmental historians and geographers); between researchers and practitioners; and most importantly between outside experts and the individuals, households and communities who are directly dependent on the island's natural resources for their livelihoods (Scales 2014c). In short, conservation and development in Madagascar needs a new paradigm.

\section{ACKNOWLEDGEMENTS}

I would like to thank Routledge for permission to reproduce material from I. R. Scales, ed. (2014) 'Conservation and Environmental Management in Madagascar'. I would also like to thank the two anonymous reviewers for their constructive comments, which helped to improve this paper. Finally, thanks to Lucienne Wilmé for inviting me to contribute this piece to the journal.

\section{REFERENCES}

Adams, W. M. 2003. Future Nature: A vision for conservation. Earthscan, London, UK.

Bekessy, S. A. and Wintle, B. A. 2008. Using carbon investment to grow the biodiversity bank. Conservation Biology 22, 3: 510-513. (doi:10.1111/ j.1523-1739.2008.00943.x)
Bond, W. J., Silander Jr., J. A., Ranaivonasy, J. and Ratsirarson, J. 2008. The antiquity of Madagascarıs grasslands and the rise of $\mathrm{C} 4$ grassy biomes. Journal of Biogeography 35, 10: 1743-1758. (doi:10.1111/ j.1365-2699.2008.01923.x)

Brimont, L. and Bidaud, C. 2014. Incentivising forest conservation: Payments for environmental services and reducing carbon emissions from deforestation. In: Conservation and Environmental Management in Madagascar. I. R. Scales (ed.), pp 299-319. Routledge London and New York.

Burney, D. A. 1987. Late holocene vegetational change in central Madagascar. Quaternary Research, 28, 1: 130-143. (doi:10.1016/0033-5894(87)90038-X)

Burney, D. A., Pigott Burney, L., Godfrey, L. R., Jungers, W. L., Goodman, S. M., Wright, H. T. and Jull, A. J. T. 2004. A chronology for late prehistoric Madagascar. Journal of Human Evolution 47, 1-2: 25-63. (doi:10.1016/j. jhevol.2004.05.005)

Carr, D. L. 2004. Proximate population factors and deforestation in tropical agricultural frontiers. Population and Environment 25, 6: 585-612. (doi:10.1023/B:POEN.0000039066.05666.8d)

Carr, D. L., Suter, L. and Barbieri, A. 2005. Population dynamics and tropical deforestation: state of the debate and conceptual challenges. Population and Environment 27, 1: 89-113. (doi:10.1007/s11111-0050014-X)

Casse, T., Milhøj, A., Ranaivoson, S. and Randriamanarivo, J. R. 2004. Causes of deforestation in southwestern Madagascar: What do we know? Forest Policy and Economics 6, 1: 33-48. (doi:10.1016/S13899341(02)00084-9)

Christie, I. T. and Crompton, D. E. 2003. Africa Region Working Paper Series No. 63 - Republic of Madagascar: Tourism sector study. World Bank, Washington. Available at <http://www.worldbank.org/afr/wps/wp63. $\mathrm{pdf}>$

Corson, C. 2010. Shifting environmental governance in a neoliberal world: USAID for conservation. Antipode 42, 3: 576-602. (doi:10.1111/j.14678330.2010.00764.X)

Corson, C. 2014. Conservation politics in Madagascar: The expansion of protected areas. In: Conservation and Environmental Management in Madagascar. I. R. Scales (ed.), pp 193-215. Routledge, London and New York.

Cronon, W. 1996. The trouble with wilderness or, getting back to the wrong nature. Environmental History 1, 1: 7-28.

Dewar, R. E. 1984. Extinctions in Madagascar: The loss of the subfossil fauna. In: Quaternary Extinctions: a Prehistoric Revolution. P. S. Martin and R. G. Klein (eds.), pp 574-593. The University of Arizona Press, Tucson, USA.

Dewar, R. E. 2014. Early human settlers and their impact on Madagascar's landscapes. In: Conservation and Environmental Management in Madagascar. I. R. Scales (ed.), pp 44-64. Routledge, London and New York.

Dressler, W., Buescher, B., Schoon, M., Brockington, D., Hayes, T., Kull, C. A., McCarthy, J. and Shrestha, K. 2010. From hope to crisis and back again? A critical history of the global CBNRM narrative. Environmental Conservation 37, 1: 5-15. (doi:10.1017/S0376892910000044)

Dryzek, J. S. 1997. The Politics of the Earth: Environmental Discourses. Oxford University Press, Oxford, UK.

Duffy, R. 2006. Non-governmental organisations and governance states: The impact of transnational environmental management networks in Madagascar. Environmental Politics 15, 5: 731-749. (doi:10.1080/09644010600937173)

Durbin, J. C. and Ratrimoarisaona, S.-N. 1996. Can tourism make a major contribution to the conservation of protected areas in Madagascar. Biodiversity and Conservation 5, 3: 345-353.

Fairhead, J., Leach, M. and Scoones, I. 2012. Green Grabbing: A new appropriation of nature. The Journal of Peasant Studies 39, 2: 237-261. (doi: 10.1080/03066150.2012.671770)

Ferguson, B. and Gardner, C. J. 2010. Looking back and thinking ahead - where next for conservation in Madagascar? Madagascar Conservation \& Development 5: 75-76.

Ferraro, P. J. 2002. The local costs of establishing protected areas in lowincome nations: Ranomafana National Park, Madagascar. Ecological Economics 43, 2-3: 261-275. (doi:10.1016/S0921-8009(02)00219-7) 
Ganzhorn, J. U., Wilmé, L. and Mercier, J.-L. 2014. Explaining Madagascar's biodiversity. In: Conservation and Environmental Management in Madagascar. I. R. Scales (ed.), pp 17-43. Routledge, London and New York.

Gasse, F. and Van Campo, E. 2001. Late Quaternary environmental changes from a pollen and diatom record in the southern tropics (Lake Tritrivakely, Madagascar). Palaeogeography Palaeoclimatology Palaeoecology 167, 3-4: 287-308. (doi:10.1016/S0031-0182(00)00242-X)

Geist, H. J. and Lambin, E. F. 2002. Proximate causes and underlying driving forces of tropical deforesation. Bioscience 52, 2: 143-150. (doi:10.1641/0006-3568(2002)052[0143:PCAUDF]2.0.CO;2)

Ghimire, K. B. 1994. Parks and people: Livelihood issues in National Parks Management in Thailand and Madagascar. Development and Change 25, 1: 195-229. (doi:10.1111/j.1467-7660.1994.tb00514.x)

Goodman, S. M. and Benstead, J. P. (eds.) 2003. The Natural History of Madagascar. University of Chicago Press, Chicago.

Goodman, S. M. and Benstead, J. P. 2005. Updated estimates of biotic diversity and endemism for Madagascar. Oryx 39, 1: 73-77. (doi:10.1017/ S0030605305000128)

Harper, J. 2002. Endangered Species: Health, Illness and Death Among Madagascarss People of the Forest. Carolina Academic Press, Durham, USA

Harper, G. J., Steininger, M. K., Tucker, C. J., Juhn, D. and Hawkins, F. 2007. Fifty years of deforestation and forest fragmentation in Madagascar. Environmental Conservation 34, 4: 325-333. (doi:10.1017/ S0376892907004262)

Hirsch, P. D., Adams, W. M., Brosius, J. P., Zia, A., Bariola, N. and Dammert, J. L. 2011. Acknowledging conservation trade-offs and embracing complexity. Conservation Biology 25, 2: 259-264. (doi:10.1111/j.15231739.2010.01608.x)

Horning, N. 2012. Debunking three myths about Madagascar's deforestation. Madagascar Conservation and Development 7, 3: 116-119. (doi:10.4314/mcd.v7i3.3)

Jarosz, L. 1993. Defining and explaining tropical deforestation: Shifting cultivation and population growth in colonial Madagascar (1896-1940). Economic Geography 69, 4: 366-379. (doi:10.2307/143595)

Jenkins, R. K. B., Keane, A., Rakotoarivelo, A. R., Rakotomboavonjy, V., Randrianandrianina, F. H., Razafimanahaka, H. J., Ralaiarimalala, S. R. and Jones, J. P. G. 2011. Analysis of patterns of bushmeat consumption reveals extensive exploitation of protected species in eastern Madagascar. PLoS ONE 6, 12: e27570. (doi:10.1371/journal. pone.0027570)

Jolly, C. L. 1994. Four theories of population change and the environment Population and Environment 16, 1: 61-90. (doi:10.1007/BF02208003)

Kaufmann, J. C. 2014. Contrasting visions of nature and landscapes. In: Conservation and Environmental Management in Madagascar. I. R. Scales (ed.), pp 320-341. Routledge, London and New York.

Keller, E. 2009. The danger of misunderstanding 'culture'. Madagascar Conservation \& Development 4, 2: 82-85. (doi:10.4314/mcd.v4i2.48647)

Kremen, C., Cameron, A., Moilanen, A., Phillips, S. J., Thomas, C. et al. 2008. Aligning conservation priorities across taxa in Madagascar with highresolution planning tools. Science 320, 5873: 222-226. (doi:10.1126/ science.1155193)

Kuhn, T. S. 1962. The Structure of Scientific Revolutions. The University of Chicago Press, Chicago.

Kull, C. A. 1996. The evolution of conservation efforts in Madagascar. International Environmental Affairs 8, 1: 50-86.

Kull, C. A. 2000. Deforestation, erosion, and fire: Degradation myths in the environmental history of Madagascar. Environment and History 6, 4: 423-450. (doi:10.3197/096734000129342361)

Kull, C. A. 2014. The roots, persistence, and character of Madagascar's conservation boom. In: Conservation and Environmental Management in Madagascar. I. R. Scales (ed.), pp 146-171. Routledge, London and New York.

MacDonald, K. I. 2010. The Devil is in the (Bio)diversity: Private sector 'engagement' and the restructuring of biodiversity conservation. Antipode 42, 3: 513-550. (doi:10.1111/j.1467-8330.2010.00762.x)

McConnell, W. J. 2002. Madagascar: Emerald isle or paradise lost? Environment 44, 8: 10-22. (doi:10.1080/00139157.2002.10544685)
McConnell, W. J. and Kull, C. A. 2014. Deforestation in Madagascar: Debates over the island's forest cover and challenges of measuring forest change. In: Conservation and Environmental Management in Madagascar. I. R. Scales (ed.), pp 67-104. Routledge, London and New York.

Mercier, J.-L. and Wilmé, L. 2013. The Eco-Geo-Clim model: explaining Madagascar's endemism. Madagascar Conservation \& Development 8, 2: 63-68. (doi:10.4314/mcd.v8i2.3)

Minten, B. and Méral, P. 2006.Commerce et Environnement: Impacts de I'exportation de maïs sur les forêts d'epineux du sud-ouest malgache. World Wild Fund For Nature, Antananarivo, Madagascar. Available at <http://www.documentation.ird.fr/hor/fdi:010044586>

Ormsby, A. and Mannie, K. 2006. Ecotourism benefits and the role of local guides at Masoala National Park, Madagascar. Journal of Sustainable Tourism 14, 3: 271-287. (doi:10.1080/09669580608669059)

Ostrom, E., Janssen, M. A. and Anderies, J. M. 2007. Going beyond panaceas. Proceedings of The National Academy of Sciences of the United States of America 104, 39: 15176-15178. (doi:10.1073/pnas.0701886104)

Peters, J. 1998. Transforming the integrated conservation and development project (ICDP) approach: Observations from the Ranomafana National Park Project, Madagascar. Journal of Agricultural and Environmental Ethics 11, 1: 17-47. (doi:10.1023/A:1007796628731)

Peters, J. 1999. Understanding conflicts between people and parks at Ranomafana, Madagascar. Agriculture and Human values 16, 1: 65-74. (doi:10.1023/A:1007572011454)

Pollini, J. 2010. Environmental degradation narratives in Madagascar: From colonial hegemonies to humanist revisionism. Geoforum 41, 5: 711-722. (doi:10.1016/j.geoforum.2010.04.001)

Pollini, J. 2011. The difficult reconciliation of conservation and development objectives: The case of the Malagasy Environmental Action Plan. Human Organization 70, 1: 74-87.

Pollini, J., Hockley, N., Muttenzer, F. D. and Ramamonjisoa, B. S. 2014. The transfer of natural resource management rights to local communities. In: Conservation and Environmental Management in Madagascar. I. R. Scales (ed.), pp 172-192. Routledge, London and New York.

Rasoavahiny, L., Andrianarisata, M., Razafimpahanana, A. and Ratsifandrihamanana, A. N. 2008. Conducting an ecological gap analysis for the new Madagascar protected area system. Parks 17, 1: 12-21.

Réau, B. 2002. Burning for zebu: The complexity of deforestation issues in western Madagascar. Norwegian Journal of Geography 56, 3: 219-229. (doi:10.1080/00291950260293048)

Richard, A. F. and Dewar, R. E. 2001. Politics, negotiation and conservation: A view from Madagascar. In: African Rain Forest Ecology and Conservation: An Interdisciplinary Perspective. W. Weber, L. J. T. White and L. Naughton-Treves (eds.), pp 535-546. Yale University Press, New Haven and London.

Scales, I. R. 2011. Farming at the forest frontier: Land use and landscape change in western Madagascar, 1896 to 2005. Environment and History 17, 4: 499-524.

Scales, I. R. 2012 Lost in translation: conflicting views of deforestation, land use and identity in western Madagascar. The Geographical Journal 178, 1: 67-79. (doi:10.1111/j.1475-4959.2011.00432.x)

Scales, I. R. (ed.) 2014. Conservation and Environmental Management in Madagascar. Routledge, London and New York.

Scales, I. R. 2014a. Conservation at the crossroads: biological diversity, environmental change and natural resource use in Madagascar. In: Conservation and Environmental Management in Madagascar. I. R. Scales (ed.), pp 1-13. Routledge, London and New York.

Scales, I. R. 2014b. The drivers of deforestation and the complexity of land use in Madagascar. In: Conservation and Environmental Management in Madagascar. I. R. Scales (ed.), pp 105-125. Routledge, London and New York.

Scales, I. R. 2014C. The future of biodiversity conservation and environmental management in Madagascar: lessons from the past and challenges ahead. In: Conservation and Environmental Management in Madagascar. I. R. Scales (ed.), pp 342-360. Routledge, London and New York.

Scales, I. R. 2014 (In press). Paying for nature: what every conservationist should know about political economy. Oryx. (doi:10.1017/ S0030605314000015) 
Schuurman, D. and Lowry II, P. P. 2009. The Madagascar rosewood massacre. Madagascar Conservation \& Development 4, 2: 98-102. (doi:10.4314/ mcd.v4i2.48649)

Schwitzer, C., Mittermeier, R., Johnson, S. E., Donati, G., Irwin, M., et al. 2014. Averting lemur extinctions amid Madagascar's political crisis. Science 343, 6173: 842-843. (doi:10.1126/science.1245783)

Seagle, C. 2012. Inverting the impacts: Mining, conservation and sustainability claims near the Rio Tinto/QMM ilmenite mine in Southeast Madagascar. Journal of Peasant Studies 39, 2: 447-477. (doi:10.1080/0 3066150.2012.671769)

Seddon, N., Tobias, J., Yount, J. W., Ramanampamonjy, J. R., Butchart, S. and Randrianizahana, H. 2000. Conservation issues and priorities in the Mikea Forest of south-west Madagascar. Oryx 34, 4: 287-304. (doi:10.1046/j.1365-3008.2000.00134.X)

Sussman, R. W., Green, G. M. and Sussman, L. K. 1994. Satellite imagery, human ecology, anthropology, and deforestation in Madagascar. Human Ecology 22, 3: 333-354. (doi:10.1007/BF02168856)

Thalmann, U. 2006. Lemurs - ambassadors for Madagascar. Madagascar Conservation \& Development 1, 1: 4-8. (doi:10.4314/mcd.v1i1.44043)

Virah-Sawmy, M. 2009. Ecosystem management in Madagascar during global change. Conservation Letters 2, 4: 163-170. (doi:10.1111/j.1755263X.2009.00066.X)

Walsh, A. 2005. The obvious aspects of ecological underprivilege in Ankarana, Northern Madagascar. American Anthropologist 107, 4: 654-665. (doi:10.1525/aa.2005.107.4.654)

Wilmé , L., Goodman, S. M. and Ganzhorn, J. U. 2006. Biogeographic evolution of Madagascar's microendemic biota. Science 312, 5776 1063-1065. (doi:10.1126/science.1122806) 